\title{
Synthesis and use of carvedilol metal complexes as carbon dioxide storage media
}

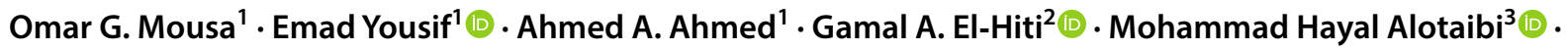 \\ Dina S. Ahmed ${ }^{4}$
}

Received: 27 July 2020 / Accepted: 14 September 2020 / Published online: 29 September 2020

(C) The Author(s) 2020

\begin{abstract}
The consequences of increased fossil fuel consumption on the environment presents a challenge. Carbon dioxide capture is a useful technique to reduce global warming. Therefore, three carvedilol metal (nickel, cobalt, and copper) complexes were synthesized as potential carbon dioxide storage media. The structural and textural properties of metal carvedilol complexes have been established using various techniques. The metal complexes have mesoporous structures in which pore size was approximately $3 \mathrm{~nm}$. Particle size ranged from 51.0 to $393.9 \mathrm{~nm}$ with a relatively small surface area $\left(6.126-9.073 \mathrm{~m}^{2} / \mathrm{g}\right)$. The carvedilol metal complexes have either type-III or IV nitrogen adsorption-desorption isotherm. The complexes showed reasonable capacity towards carbon dioxide uptake (up to $18.21 \mathrm{~cm}^{3} / \mathrm{g}$ ) under the optimized condition (40 bar and $323 \mathrm{~K}$ ).
\end{abstract}

\section{Graphical Abstract}
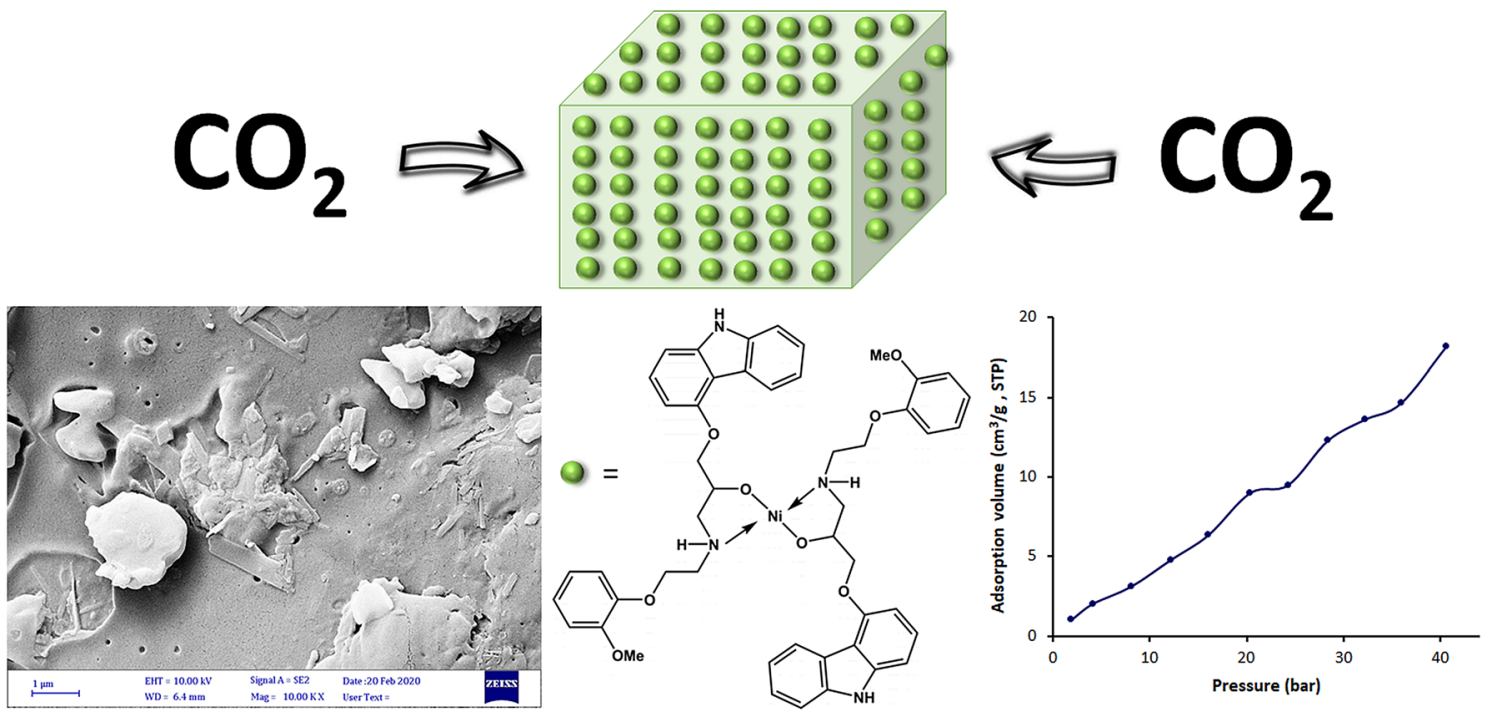

Keywords Carvedilol metal complexes $\cdot$ Carbon dioxide storage media $\cdot$ Mesoporous materials $\cdot$ Nitrogen adsorptiondesorption isotherms $\cdot$ Pore size $\cdot$ Surface area

Emad Yousif

emadayousif@gmail.com

$\bowtie$ Gamal A. El-Hiti

gelhiti@ksu.edu.sa

$\triangle$ Mohammad Hayal Alotaibi mhhalotaibi@kacst.edu.sa

Extended author information available on the last page of the article

\section{Introduction}

The reduction of environmental pollution produced due to the excessive use of energy is a challenge that requires attention $[1,2]$. Fossil fuels are the most used energy source. 
Their combustion contributes $(60 \%)$ to the increased level of carbon dioxide $\left(\mathrm{CO}_{2}\right)$ and in particular from industrial sources [3]. The high atmospheric $\mathrm{CO}_{2}$ concentration leads to devastating environmental changes, ultimately contributing to climate change [4]. Hydrogen is a clean energy source and its use can overcome some of the disadvantages associated with fossil fuels. However, it cannot fully replace fossil fuels in the near future. The reduction of $\mathrm{CO}_{2}$ concentration in the environment through its capture is an important strategy [5]. Various inexpensive materials have been designed to act as storage media for $\mathrm{CO}_{2}[6-10]$. The use of chemical absorbents showed some success [11]. However, the process involves the use of volatile absorbents, requires high energy, and has a high operating costs [12]. Therefore, different processes for the capture of $\mathrm{CO}_{2}$ have been developed. These processes should be simple, efficient and require low energy consumption, [13].

Materials with high adsorption capacity such as ionic liquids, zeolites, silica, and activated carbons have been used to capture $\mathrm{CO}_{2}$ [14-18]. However, limited progress has been achieved since ionic liquids are expensive to recycle and zeolites are highly hydrophilic and not suitable for flue gases [19]. Materials containing carbon such as resins, biomass, and polymers have high stability and surface area, are cheap to produce, and easy to modify, but they have poor selectivity [20]. In addition, the process involves the use of carbonate or hydroxide as a base [21]. Metal-organic frameworks (MOFs) have been used as adsorbents for $\mathrm{CO}_{2}$ since they have large surface area [22, 23]. A strong interaction exist between $\mathrm{CO}_{2}$ and MOFs due to hydrogen bonding. Such interaction requires a low adsorption heat [24]. The MOFs storage capacity of $\mathrm{CO}_{2}$ can be enhanced through by incorporating polar groups within their skeletons [25]. Porous-organic polymers (POPs) have many qualities to act as adsorbents for $\mathrm{CO}_{2}$ [19]. They have high surface area, stability, adsorption capacity, tunable pores, and their structures can be easily modified. In addition, various functional groups (organic and inorganic) can be incorporated within their skeletons [26]. Moreover, they contain heteroatoms that facilitate the capture of $\mathrm{CO}_{2}$ [19]. These qualities make them good candidates to be used as media for the storage of $\mathrm{CO}_{2}$ [27]. However, the POPs synthetic procedures still need optimization and to be simplified [28]. Recently, various porous materials have been designed, synthesized, and used as gas storage media [29-39]. Similarly, covalent organic frameworks (COFs) are nanoporous materials that have strong covalent bonds and can be used in gas adsorption and separation [40].

The current work report the synthesis, properties, and use of three metal complexes containing carvedilol as $\mathrm{CO}_{2}$ storage media. Carvedilol is inexpensive, commercially available, non-toxic, has a high molecular weight and it is expected to have some adsorption characteristics.

\section{Materials and methods}

\section{General}

Chemicals, reagents, and solvents were obtained from Merck. The melting points were recorded on MPD Mitamura Riken Kogyo apparatus. The FTIR spectra ( $\mathrm{KBr}$ disc) were recorded on 8300 Shimadzu Spectrophotometer. The magnetic susceptibility was measured on a Bruker BM6 instrument. The conductivity was measured in dimethyl sulfoxide $\left(10^{-3} \mathrm{~mol} / \mathrm{L}\right)$ at $25^{\circ} \mathrm{C}$ using a WTW ProfiLine Oxi $3205 \mathrm{~m}$. The surface morphology was examined on a TESCAN MIRA3 microscope $(15 \mathrm{kV})$. The $\mathrm{CO}_{2}$ adsorbed over metal complexes was measured on an $\mathrm{H}$-sorb 2600 high-pressure volumetric adsorption analyzer.

\section{Synthesis}

A solution of carvedilol $(0.81 \mathrm{~g}, 2.0 \mathrm{mmol})$ in methanol (MeOH; $20 \mathrm{~mL}$ ) was slowly added to a stirred solution of metal chloride $\left(\mathrm{NiCl}_{2} \cdot 6 \mathrm{H}_{2} \mathrm{O}, \mathrm{CuCl}_{2} \cdot 4 \mathrm{H}_{2} \mathrm{O}\right.$, or $\mathrm{CoCl}_{2} \cdot 6 \mathrm{H}_{2} \mathrm{O}$; $1.0 \mathrm{mmol})$ in $\mathrm{MeOH}(10 \mathrm{~mL})$. The mixture was refluxed for $3 \mathrm{~h}$ and then cooled to room temperature. The solid was removed by filtration, washed with $\mathrm{MeOH}(2 \times 10 \mathrm{~mL})$, and dried to give the corresponding metal complex. The yield (\%) and melting point $\left({ }^{\circ} \mathrm{C}\right)$ for each complex is reported in Table 1.

\section{Nitrogen gas adsorption}

The metal complexes were dried at $60{ }^{\circ} \mathrm{C}$ for $8 \mathrm{~h}$ prior to the measurements. The specific surface area was measured from the nitrogen adsorption isotherms at $77 \mathrm{~K}$ using the Brunauer-Emmett-Teller (BET) method. Pore volume and
Table 1 Melting point, yield, and elemental analysis of carvedilol metal complexes

\begin{tabular}{lrlllll}
\hline Complex & Mp. $\left({ }^{\circ} \mathrm{C}\right)$ & Yield (\%) & \multicolumn{4}{l}{ Calculated (Found; \%) } \\
\cline { 3 - 7 } & & & $\mathrm{C}$ & $\mathrm{H}$ & $\mathrm{N}$ & $\mathrm{M}$ \\
\hline $\mathrm{Ni}(\mathrm{II})$ & $130-131$ & 81 & $66.29(66.33)$ & $5.80(5.83)$ & $6.44(6.45)$ & $6.75(6.79)$ \\
$\mathrm{Cu}(\mathrm{II})$ & $98-99$ & 77 & $65.93(65.95)$ & $5.76(5.79)$ & $6.41(6.42)$ & $7.27(7.32)$ \\
$\mathrm{Co}(\mathrm{II})$ & $91-92$ & 72 & $66.28(66.30)$ & $5.79(5.83)$ & $6.44(6.45)$ & $6.77(6.80)$ \\
\hline
\end{tabular}


pore size were determined using the Barrett-Joyner-Halenda (BJH) method.

\section{Carbon dioxide storage}

A sample of metal complex (1.0 g) was degassed in a vacuum oven $\left(2 \mathrm{~h} ; 40{ }^{\circ} \mathrm{C}\right)$ to remove traces of moisture and solvent that might be trapped in the pores. The $\mathrm{CO}_{2}$ adsorption experiment was performed at different pressures for optimization.

\section{Results and discussion}

\section{Synthesis and characterization}

Reaction of excess carvedilol (two mole equivalents) and hydrated metal chlorides (nickel, copper, and cobalt; one mole equivalent) in boiling $\mathrm{MeOH}$ for $3 \mathrm{~h}$ gave the corresponding carvedilol metal complexes (Scheme 1) as green solids in high yields (Table 1).

The FTIR spectra of carvedilol metal complexes showed no absorption band for the $\mathrm{OH}$ group. They showed the appearance of bands corresponding to the $\mathrm{M}-\mathrm{O}$ bonds $\left(455-470 \mathrm{~cm}^{-1}\right)$ [41] and aliphatic $\left(3394-3410 \mathrm{~cm}^{-1}\right)$ and aromatic $\mathrm{N}-\mathrm{H}\left(3240-3275 \mathrm{~cm}^{-1}\right.$ ) bonds (Table 2). The high shift in the stretching vibration of aliphatic $\mathrm{N}-\mathrm{H}$ indicated that coordination with metals has taken place. Based on molar conductivity $(10-12 \mu \mathrm{S} / \mathrm{cm})$, the complexes are nonelectrolytes in which no ions exist in solution [42]. The $\mathrm{Ni}$ (II) complex has a magnetic moment of 3.24 BM, which indicates a high spin octahedral structure [43]. While $\mathrm{Cu}(\mathrm{II})$ complex has a magnetic moment of $1.74 \mathrm{BM}$ which is comparable with a slightly pseudo octahedral geometry [44]. For the $\mathrm{Co}$ (II) complex, the magnetic moment was $4.32 \mathrm{BM}$ which is consistent for a tetrahedral geometry [42].

\section{Field emission scanning electron microscopy}

The field emission scanning electron microscopy (FESEM) was used to inspect the surface of carvedilol metal complexes (Fig. 1). The surfaces of the complexes were amorphous, uniform, contained grooved networks, and irregular blocks, and have a long range of pore dimensions $(93.8-274.5 \mathrm{~nm})$ [45]. The grooves were parallel to each other and perpendicular to the outer surface of complexes. These properties could help the particles' porosity to enable gas capture [32]. The particles sizes of $\mathrm{Ni}(\mathrm{II}), \mathrm{Cu}$ (II) and $\mathrm{Co}$ (II) complexes were 51.0-116.6, 93.8-274.5 and $67.5-393.9 \mathrm{~nm}$, respectively.

\section{Porosity}

The BET method was used to analyze the texture properties of carvedilol metal complexes. The nitrogen $\left(\mathrm{N}_{2}\right)$ adsorption-desorption isotherms of carvedilol metal complexes
Scheme 1 Synthesis of carvedilol metal complexes

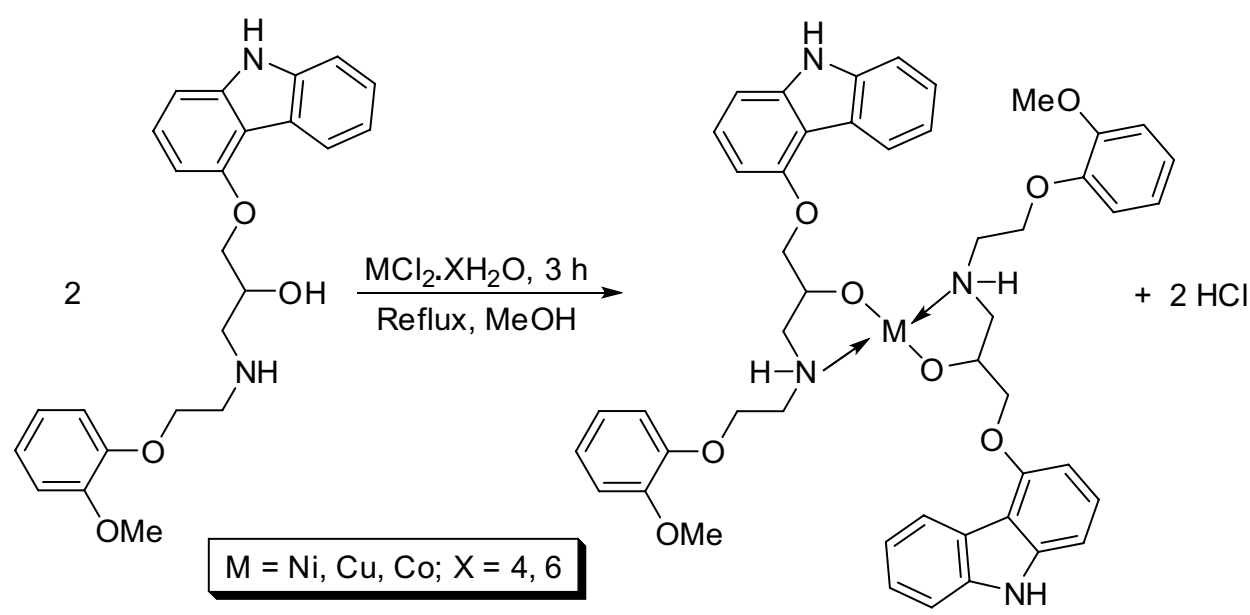

Table 2 Selected FTIR data, conductivity, and magnetic moment of carvedilol metal complexes

\begin{tabular}{|c|c|c|c|c|c|c|}
\hline \multirow[t]{2}{*}{ Complex } & \multicolumn{4}{|c|}{ Wavenumber $\left(\mathrm{cm}^{-1}\right)$} & \multirow{2}{*}{$\begin{array}{l}\text { Conductivity } \\
(\mu \mathrm{S} / \mathrm{cm})\end{array}$} & \multirow{2}{*}{$\begin{array}{l}\text { Magnetic } \\
\text { moment } \\
\text { (BM) }\end{array}$} \\
\hline & NH (Ali) & $\mathrm{NH}(\mathrm{Ar})$ & $\mathrm{M}-\mathrm{O}$ & $\mathrm{M}-\mathrm{N}$ & & \\
\hline $\mathrm{Ni}(\mathrm{II})$ & 3410 & 3240 & 462 & 424 & 11 & 3.24 \\
\hline $\mathrm{Cu}(\mathrm{II})$ & 3394 & 3251 & 470 & 439 & 10 & 1.74 \\
\hline Co(II) & 3402 & 3275 & 455 & 435 & 12 & 4.32 \\
\hline
\end{tabular}




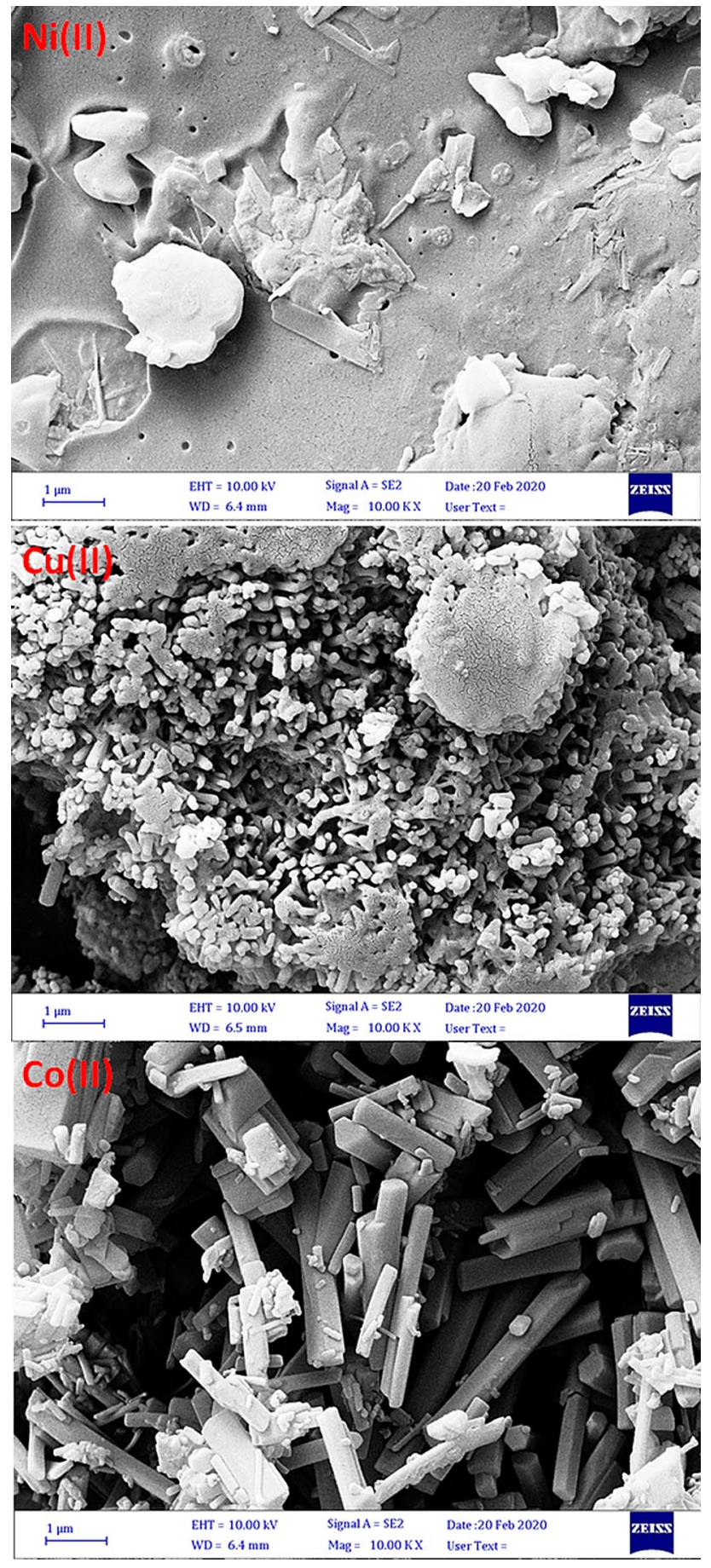

Fig. 1 FESEM images of carvedilol metal complexes

were studied at $77 \mathrm{~K}$ at different pressures (Fig. 2). The $\mathrm{Cu}(\mathrm{II})$ complex has a type-III sorption isotherm with no identifiable monolayer formation [46, 47]. On the other hand, the $\mathrm{Ni}$ (II) and $\mathrm{Co}$ (II) complexes have type-IV isotherms that contained a sharp bend at the beginning of curves due to monolayer formation followed by hysteresis as a result of van der Waals force increase [31].
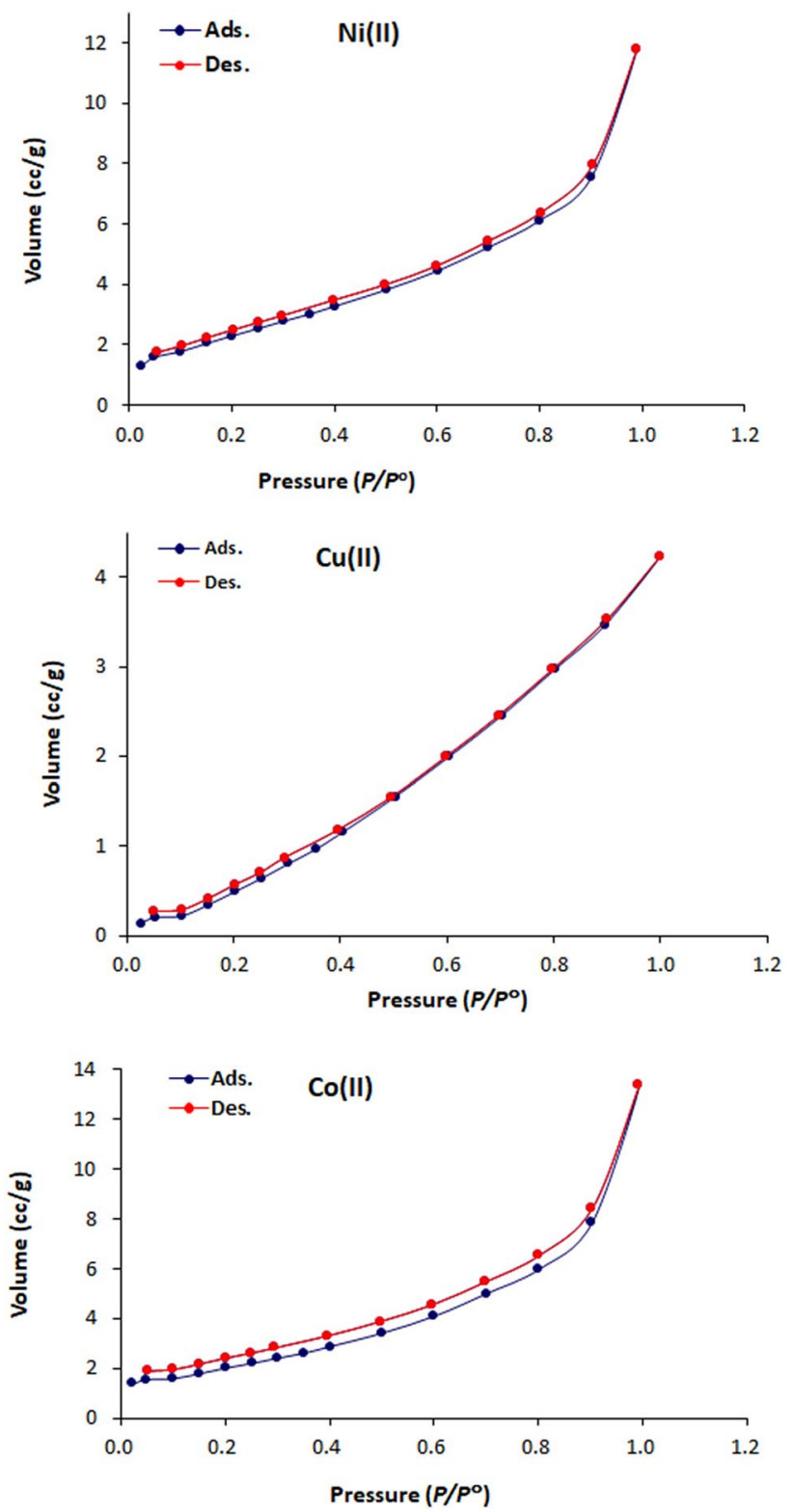

Fig. $2 \mathrm{~N}_{2}$ Adsorption-desorption isotherms of carvedilol metal complexes

The BET method was used to calculate the surface area of complexes $\left(6.126-9.073 \mathrm{~m}^{2} / \mathrm{g}\right)$. While, the $\mathrm{BJH}$ model was used to determine pore size. The pore size was approximately $3 \mathrm{~nm}$ (Table 3 ) which indicate mesoporous

Table 3 Porosity properties of carvedilol metal complexes

\begin{tabular}{llll}
\hline Complexes & $S_{\text {BET }}\left(\mathrm{m}^{2} / \mathrm{g}\right)$ & $V_{\text {Total }}\left(\mathrm{cm}^{3} / \mathrm{g}\right)$ & Pore size $(\mathrm{nm})$ \\
\hline $\mathrm{Ni}(\mathrm{II})$ & 9.073 & 0.021 & 3.082 \\
$\mathrm{Co}(\mathrm{II})$ & 7.803 & 0.020 & 3.079 \\
$\mathrm{Cu}(\mathrm{II})$ & 6.126 & 0.008 & 3.078 \\
\hline
\end{tabular}


structures [48]. The pore size distribution of carvedilol metal complexes is shown in Fig. 3. The Ni(II) complex has the highest surface area and total pore volume.
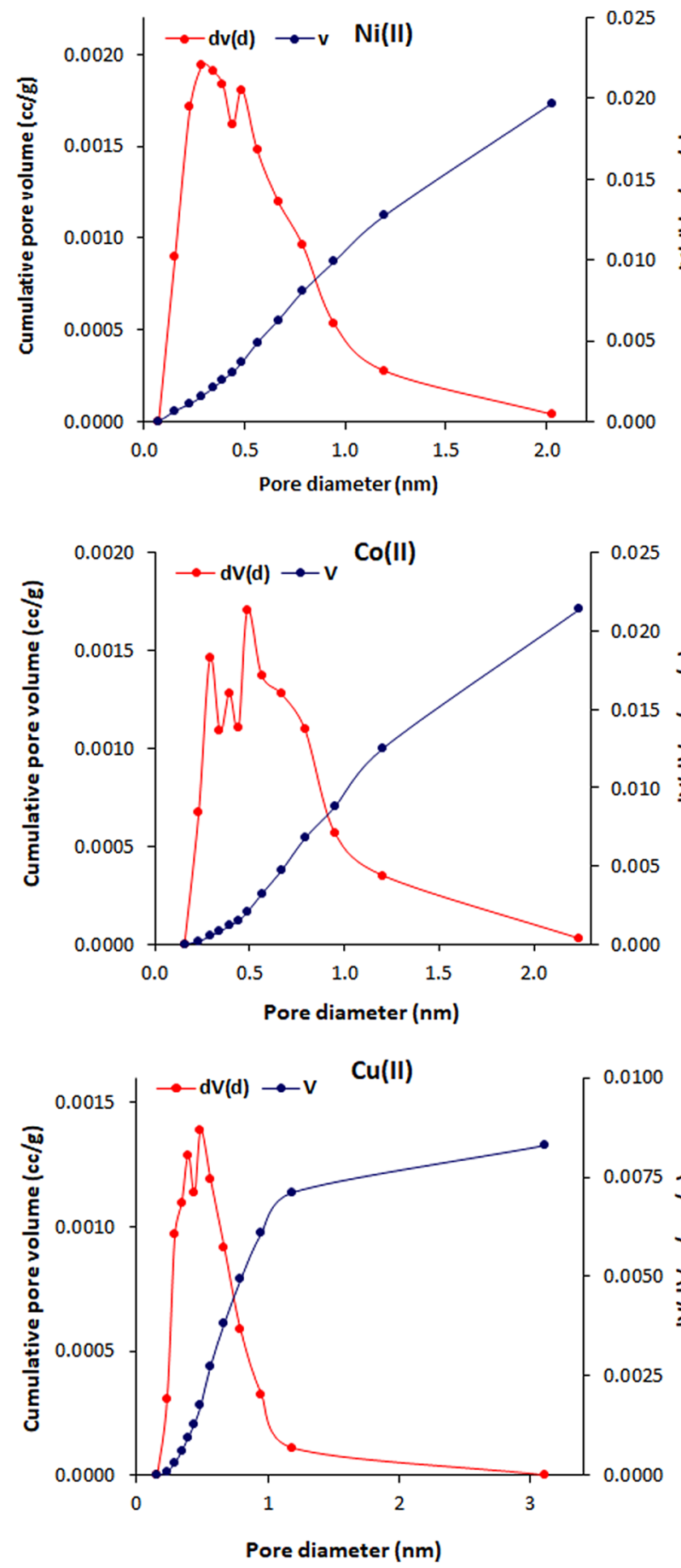

Fig. 3 Pore size distribution of carvedilol metal complexes

\section{$\mathrm{CO}_{2}$ storage capacity}

Carvedilol metal complexes showed a reasonable $\mathrm{CO}_{2}$ uptake (Fig. 4 and Table 4). The $\mathrm{CO}_{2}$ uptake depends on the strength of interaction between gas and complex, and surface area and pore dimensions of the adsorbent [49]. The order of $\mathrm{CO}_{2}$ uptake was $\mathrm{Ni}>\mathrm{Co}>\mathrm{Cu}$, which is consistent with the order of both surface area and total pore volume. The Ni(II) complex has a high charge density compared to the others [50].

Schiff bases containing melamine showed good $\mathrm{CO}_{2}$ uptake (up to $10 \mathrm{wt} \%$ ), however, they have small surface area (up to $11.6 \mathrm{~m}^{2} / \mathrm{g}$ ) [30]. Similarly, porous polyphosphates containing benzidine units in their skeleton have small surface area (up to $30 \mathrm{~m}^{2} / \mathrm{g}$ ), but adsorbed $\mathrm{CO}_{2}$ efficiently (up to $14 \mathrm{wt} \%$ ) [36]. On the other hand, polyphosphates that have 1,4-diaminobenzene units have relatively large surface area (up to $213.5 \mathrm{~m}^{2} / \mathrm{g}$ ), but their efficiencies towards adsorption of $\mathrm{CO}_{2}$ was very low $(0.6 \mathrm{wt} \%)$ [32]. Tin complexes containing telmisartan have surface area up to $130.4 \mathrm{~m}^{2} / \mathrm{g}$ and $\mathrm{CO}_{2}$ uptake over $7 \mathrm{wt} \%$ [33]. Clearly, surface area plays a role in adsorption process, but other factors such as pore size and diameter are also important. In principle, materials that have high surface area are better $\mathrm{CO}_{2}$ adsorbents. For example, polyacrylonitrile carbon fibers adsorbed $\mathrm{CO}_{2}$ efficiently

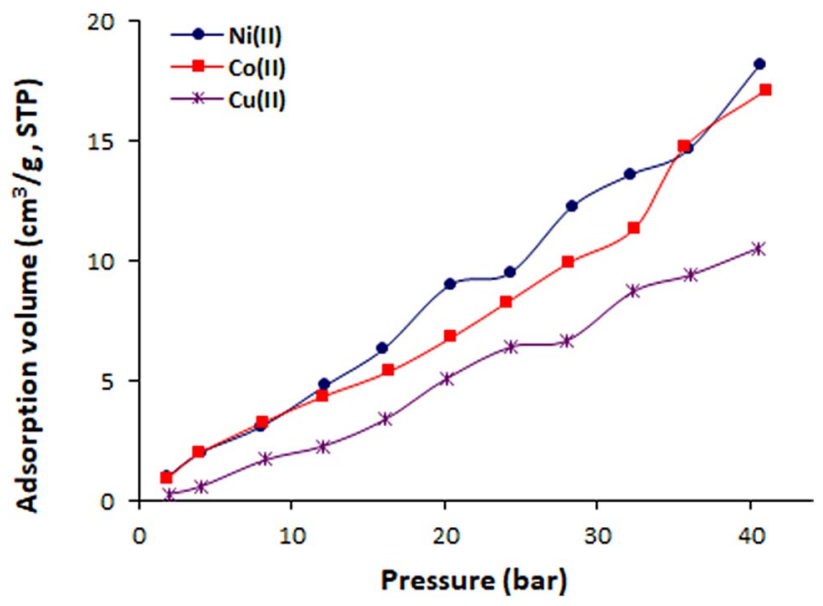

Fig. $4 \mathrm{CO}_{2}$ adsorption isotherms of carvedilol metal complexes

Table $4 \mathrm{CO}_{2}$ uptake of carvedilol metal complexes at $323 \mathrm{~K}$ and 40 bar

\begin{tabular}{llll}
\hline Complex & \multicolumn{2}{l}{$\mathrm{CO}_{2}$ uptake } & \\
\cline { 2 - 4 } & $\mathrm{cm}^{3} / \mathrm{g}$ & $\mathrm{mmol} / \mathrm{g}$ & $\mathrm{Wt} \%$ \\
\hline $\mathrm{Ni}(\mathrm{II})$ & 18.21 & 0.81 & 3.5 \\
$\mathrm{Cu}(\mathrm{II})$ & 10.54 & 0.47 & 2.1 \\
$\mathrm{Co}(\mathrm{II})$ & 17.13 & 0.76 & 3.3 \\
\hline
\end{tabular}


$(2.74 \mathrm{mmol} / \mathrm{g})$ at room temperature and normal pressure, in the presence of a base [18]. At a similar condition, porous nanocarbons that have large surface area $\left(1114 \mathrm{~m}^{2} / \mathrm{g}\right)$ leads to a $\mathrm{CO}_{2}$ uptake of $4.60 \mathrm{mmol} / \mathrm{g}$ in the presence of ethylenediamine and potassium oxalate [17]. On the other hand, porous nanocarbons that have small surface area $\left(439 \mathrm{~m}^{2} / \mathrm{g}\right)$ leads to a lower $\mathrm{CO}_{2}$ adsorption (1.94 mmol/g) [17]. Silica matrix contacting ionic liquids have a very small surface area (up to $9 \mathrm{~m}^{2} / \mathrm{g}$ ) and poor $\mathrm{CO}_{2}$ adsorption capacity $(0.35 \mathrm{~g}$ of $\mathrm{CO}_{2}$ per $\mathrm{g}$ of adsorbent) [15].

\section{Conclusions}

Three carvedilol metal complexes were synthesized in good yields and their structures and properties were established. The synthesised complexes have mesoporous structures and type-III or IV nitrogen adsorption-desorption isotherm. They have a relatively small surface area, and reasonable carbon dioxide adsorption capacity. Nickel and cobalt complexes showed higher carbon dioxide uptake compared to the copper complexes, possibly due to their relatively high surface area and total pore volume compared to the others.

Acknowledgements The authors are grateful to the Deanship of Scientific Research, King Saud University for funding through Vice Deanship of Scientific Research Chairs. We thank Al-Nahrain University for technical support.

Open Access This article is licensed under a Creative Commons Attribution 4.0 International License, which permits use, sharing, adaptation, distribution and reproduction in any medium or format, as long as you give appropriate credit to the original author(s) and the source, provide a link to the Creative Commons licence, and indicate if changes were made. The images or other third party material in this article are included in the article's Creative Commons licence, unless indicated otherwise in a credit line to the material. If material is not included in the article's Creative Commons licence and your intended use is not permitted by statutory regulation or exceeds the permitted use, you will need to obtain permission directly from the copyright holder. To view a copy of this licence, visit http://creativecommons.org/licenses/by/4.0/.

\section{References}

1. Férey G, Serre C, Devic T, Maurin G, Jobic H, Llewellyn PL, De Weireld G, Vimont A, Daturi M, Chang J-S (2011) Why hybrid porous solids capture greenhouse gases? Chem Soc Rev 40:550562. https://doi.org/10.1039/C0CS00040J

2. Sun H, Xin Q, Ma Z, Lan S (2019) Effects of plant diversity on carbon dioxide emissions and carbon removal in laboratory-scale constructed wetland. Environ Sci Pollut Res 26:5076-5082. https ://doi.org/10.1007/s11356-018-3988-5

3. Yaumi AL, Bakar MZA, Hameed BH (2017) Recent advances in functionalized composite solid materials for carbon dioxide capture. Energy 124:461-480. https://doi.org/10.1016/j.energ y.2017.02.053

4. Sanz-Pérez ES, Murdock CR, Didas SA, Jones CW (2016) Direct capture of $\mathrm{CO}_{2}$ from ambient air. Chem Rev 116:11840-11876. https://doi.org/10.1021/acs.chemrev.6b00173

5. Mukherjee A, Okolie JA, Abdelrasoul A, Niu C, Dalai AK (2019) Review of post-combustion carbon dioxide capture technologies using activated carbon. J Environ Sci 83:46-63. https://doi. org/10.1016/j.jes.2019.03.014

6. Shukla SK, Khokarale SG, Bui TQ, Mikkola J-PT (2019) Ionic liquids: potential materials for carbon dioxide capture and utilization. Front Mater 6:42. https://doi.org/10.3389/fmats.2019.00042

7. Goh K, Karahan HE, Yang E, Bae T-H (2019) Graphene-based membranes for $\mathrm{CO}_{2} / \mathrm{CH}_{4}$ separation: Key challenges and perspectives. Appl Sci 9:2784. https://doi.org/10.3390/app9142784

8. Kelektsoglou K (2018) Carbon capture and storage: a review of mineral storage of $\mathrm{CO}_{2}$ in Greece. Sustainability 10:4400. https ://doi.org/10.3390/su10124400

9. Aminua MD, Nabavia SA, Rochelleb CA, Manovica V (2017) A review of developments in carbon dioxide storage. Appl Energy 208:1389-1419. https://doi.org/10.1016/j.apenergy.2017.09.015

10. Leung DYC, Caramanna G, Maroto-Valer MM (2014) An overview of current status of carbon dioxide capture and storage technologies. Renew Sust Energy Rev 39:426-443. https://doi. org/10.1016/j.rser.2014.07.093

11. Thomas DM, Mechery J, Paulose SV (2016) Carbon dioxide capture strategies from flue gas using microalgae: a review. Environ Sci Pollut Res 23:16926-16940. https://doi. org/10.1007/s11356-016-7158-3

12. Luis $\mathrm{P}$ (2016) Use of monoethanolamine (MEA) for $\mathrm{CO}_{2}$ capture in a global scenario: consequences and alternatives. Desalination 380:93-99. https://doi.org/10.1016/j.desal.2015.08.004

13. Asadi-Sangachini Z, Galangash MM, Younesi H, Nowrouzi M (2019) The feasibility of cost-effective manufacturing activated carbon derived from walnut shells for large-scale $\mathrm{CO}_{2}$ capture. Environ Sci Pollut Res 26:26542-26552. https://doi. org/10.1007/s11356-019-05842-3

14. Lu C, Bai H, Su F, Chen W, Hwang JF, Lee H-H (2010) Adsorption of carbon dioxide from gas streams via mesoporous spherical-silica particles. J Air Waste Manag Assoc 60:489-496. https ://doi.org/10.3155/1047-3289.60.4.489

15. Aquino AS, Vieira MO, Ferreira ASD, Cabrita EJ, Einloft S, de Souza MO (2019) Hybrid ionic liquid-silica xerogels applied in $\mathrm{CO}_{2}$ capture. Appl Sci 9:2614. https://doi.org/10.3390/app91 32614

16. Hauchhum L, Mahanta P (2014) Carbon dioxide adsorption on zeolites and activated carbon by pressure swing adsorption in a fixed bed. Int J Energy Environ Eng 5:349-356. https://doi. org/10.1007/s40095-014-0131-3

17. Staciwa P, Narkiewicz U, Moszyński D, Wróbel RJ, Cormia RD (2019) Carbon spheres as $\mathrm{CO}_{2}$ sorbents. Appl Sci 9:3349. https ://doi.org/10.3390/app9163349

18. Chiang Y-C, Yeh CY, Weng CH (2019) Carbon dioxide adsorption on porous and functionalized activated carbon fibers. Appl Sci 9:1977. https://doi.org/10.3390/app9101977

19. Wang W, Zhou M, Yuan D (2017) Carbon dioxide capture in amorphous porous organic polymers. J Mater Chem A 5:13341347. https://doi.org/10.1039/C6TA09234A

20. Wang R, Lang YX (2014) Effect of surface area and heteroatom of porous carbon materials on electrochemical capacitance in aqueous and organic electrolytes. Sci China Chem 57:15701578. https://doi.org/10.1007/s11426-014-5123-x

21. Pari G, Darmawan S, Prihandoko B (2014) Porous carbon spheres from hydrothermal carbonization and $\mathrm{KOH}$ activation on cassava and tapioca flour raw material. Procedia Environ Sci 20:342-351. https://doi.org/10.1016/j.proenv.2014.03.043 
22. Férey G (2008) Hybrid porous solids: past, present, future. Chem Soc Rev 37:191-214. https://doi.org/10.1039/B618320B

23. Millward AR, Yaghi OM (2005) Metal-organic frameworks with exceptionally high capacity for storage of carbon dioxide at room temperature. J Am Chem Soc 127:17998-17999. https ://doi.org/10.1021/ja0570032

24. Choi S, Drese JH, Jones CW (2009) Adsorbent materials for carbon dioxide capture from large anthropogenic point sources. Chemsuschem 2:796-854. https://doi.org/10.1002/cssc.20090 0036

25. Lu W, Yuan D, Sculley J, Zhao D, Krishna R, Zhou HC (2011) Sulfonate-grafted porous polymer networks for preferential $\mathrm{CO}_{2}$ adsorption at low pressure. J Am Chem Soc 133:18126-18129. https://doi.org/10.1021/ja2087773

26. Rabbani MG, Reich TE, Kassab RM, Jackson KT, El-Kaderi HM (2012) High $\mathrm{CO}_{2}$ uptake and selectivity by triptycene-derived benzimidazole-linked polymers. Chem Commun 48:1141-1143. https://doi.org/10.1039/C2CC16986J

27. Dawson R, Cooper AI, Adams DJ (2012) Nanoporous organic polymer networks. Prog Polym Sci 37:530-563. https://doi. org/10.1016/j.progpolymsci.2011.09.002

28. Ahmed DS, El-Hiti GA, Yousif E, Ali AA, Hameed AS (2018) Design and synthesis of porous polymeric materials and their applications in gas capture and storage: a review. J Polym Res 25:75. https://doi.org/10.1007/s10965-018-1474-x

29. Najim LH, El-Hiti GA, Ahmed DS, Mohammed A, Alotaibi MH, Yousif E (2020) Valsartan metal complexes as capture and reversible storage media for methane. Appl Petrochem Res a head of print. https://doi.org/10.1007/s13203-020-00247-7

30. Omer RM, Al-Tikrity ETB, El-Hiti GA, Alotibi MF, Ahmed DS, Yousif E (2020) Porous aromatic melamine Schiff bases as highly efficient media for carbon dioxide storage. Processes 8:17. https:// doi.org/10.3390/pr8010017

31. Mohammed A, Yousif E, El-Hiti GA (2020) Synthesis and use of valsartan metal complexes as media for carbon dioxide storage. Materials 13:1183. https://doi.org/10.3390/ma13051183

32. Satar HA, Ahmed AA, Yousif E, Ahmed DS, Alotibi MF, El-Hiti GA (2019) Synthesis of novel heteroatom-doped porous-organic polymers as environmentally efficient media for carbon dioxide storage. Appl Sci 9:4314. https://doi.org/10.3390/app9204314

33. Hadi AG, Jawad K, Yousif E, El-Hiti GA, Alotaibi MH, Ahmed DS (2019) Synthesis of telmisartan organotin(IV) complexes and their use as carbon dioxide capture media. Molecules 24:1631. https://doi.org/10.3390/molecules24081631

34. Zare A, Khanipour M, Sarverstani HK, Kakavandi IA, Shokroo EJ, Farniaei M, Baghbani M (2019) Hydrogen and carbon dioxide recovery from the petrochemical flare gas to methanol production using adsorption and absorption combined high-efficient method. Appl Petrochem Res 9:127-145. https://doi.org/10.1007/s1320 3-019-0232-2

35. Wang K, Yan X, Komarneni S (2018) $\mathrm{CO}_{2}$ Adsorption by several types of pillared Montmorillonite clays. Appl Petrochem Res 8:173-177. https://doi.org/10.1007/s13203-018-0206-9

36. Ahmed DS, El-Hiti GA, Yousif E, Hameed AS, Abdalla M (2017) New eco-friendly phosphorus organic polymers as gas storage media. Polymers 9:336. https://doi.org/10.3390/polym9080336

37. Wilson MH, Mohler DT, Groppo JG, Grubbs T, Kesner S, Frazar EM, Shea A, Crofcheck C, Crocke M (2016) Capture and recycle of industrial $\mathrm{CO}_{2}$ emissions using microalgae. Appl Petrochem Res 6:279-293. https://doi.org/10.1007/s13203-016-0162-1
38. Takht Ravanchi M, Sahebdelfar S (2014) Carbon dioxide capture and utilization in petrochemical industry: potentials and challenges. Appl Petrochem Res 4:63-77. https://doi.org/10.1007/ s13203-014-0050-5

39. Vijayaraghavan R (2013) Noble metal ion-substituted ceria as efficient oxygen storage catalysts for clean combustion of fuels. Appl Petrochem Res 3:79-82. https://doi.org/10.1007/s1320 3-013-0032-z

40. Thomas A (2010) Functional materials: from hard to soft porous frameworks. Angew Chem Int Ed 49:8328-8344. https://doi. org/10.1002/anie.201000167

41. Refat MS, Mohamed GG, El-Sayed MY, Killa HMA, Fetooh $\mathrm{H}$ (2017) Spectroscopic and thermal degradation behavior of $\mathrm{Mg}(\mathrm{II}), \mathrm{Ca}(\mathrm{II}), \mathrm{Ba}$ (II) and $\mathrm{Sr}(\mathrm{II})$ complexes with paracetamol drug. Arab J Chem 10:S2376-S2387. https://doi.org/10.1016/j. arabjc.2013.08.017

42. Dodoff NI, Kovala-Demertzi D, Kubiak M, Kuduk-Jaworska J, Kochel A, Gorneva GA (2006) Dimethyl sulfoxide containing platinum(II) and palladium(II) chelate complexes of glyoxylic and pyruvic acid thiosemicarbazones. A new class of cytotoxic metal complexes. Z Naturforsch B Chem Sci 61:1110-1122. https ://doi.org/10.1515/znb-2006-0909

43. Ferenc W, Walków-Dziewulska A, Sarzynski J, Paszkowska B (2006) Magnetic, thermal and spectral properties of Ni(II) 2,3-, 3,5- and 2,6-dimethoxybenzoates. Ecl Quím São Paulo 31:53-60. https://doi.org/10.1590/S0100-46702006000300007

44. Majeed A, Yousif E, Farina Y (2010) Synthesis and characterization of transition metal complexes of 2-thioacetic acid benzothiazole ligand. J Al-Nahrain Uni 13:36-42. https://doi.org/10.22401/ JNUS.13.1.05

45. Sikdar S, Ghosh A, Saha R (2020) Synthesis of MgO micro-rods coated with charred dextrose and its application for the adsorption of selected heavy metals from synthetic and real groundwater. Environ Sci Pollut Res 27:17738-17753. https://doi.org/10.1007/ s11356-020-08106-7

46. Thommes M, Kaneko K, Neimark AV, Olivier JP, RodriguezReinoso F, Rouquerol J, Sing KSW (2015) Physisorption of gases, with special reference to the evaluation of surface area and pore size distribution (IUPAC Technical Report). Pure Appl Chem 87:1051-1069. https://doi.org/10.1515/pac-2014-1117

47. Cychosz KA, Thommes M (2018) Progress in the physisorption characterization of nanoporous gas storage materials. Engineering 4:559-566. https://doi.org/10.1016/j.eng.2018.06.001

48. Sing KSW, Everett DH, Haul RAW, Moscou L, Pieroti RA, Rouquerol J, Siemieniewska T (1985) Reporting physisorption data for gas/solid systems with special reference to the determination of surface area and porosity. Pure Appl Chem 57:603-619. https://doi.org/10.1515/iupac.57.0007

49. Noro S-I, Kitaura R, Kondo M, Kitagawa S, Ishii T, Matsuzaka H, Yamashita M (2002) Framework engineering by anions and porous functionalities of $\mathrm{cu}(\mathrm{II}) / 4,4$ '-bpy coordination polymers. J Am Chem Soc 124:2568-2583. https://doi.org/10.1021/ja011 3192

50. Chaemchuen S, Zhou K, Kabir NA, Chen Y, Ke X, Van Tendeloo G, Verpoort F (2015) Tuning metal sites of DABCO MOF for gas purification at ambient conditions. Micropor Mesopor Mat 201:277-285. https://doi.org/10.1016/j.micromeso.2014.09.038

Publisher's Note Springer Nature remains neutral with regard to jurisdictional claims in published maps and institutional affiliations. 


\section{Affiliations}

Omar G. Mousa ${ }^{1} \cdot$ Emad Yousif $^{1}$ (D) - Ahmed A. Ahmed ${ }^{1} \cdot$ Gamal A. El-Hiti ${ }^{2}$ (D) Mohammad Hayal Alotaibi $^{3}$ (I)

Dina S. Ahmed ${ }^{4}$

1 Department of Chemistry, College of Science, Al-Nahrain University, Baghdad 64021, Iraq

2 Cornea Research Chair, Department of Optometry, College of Applied Medical Sciences, King Saud University,

P.O. Box 10219, Riyadh 11433, Saudi Arabia
3 King Abdulaziz City for Science and Technology, National Center for Petrochemicals Technology, P.O. Box 6086, Riyadh 11442, Saudi Arabia

4 Department of Medical Instrumentation Engineering, AlMansour University College, Baghdad 64021, Iraq 